\title{
ODBICIE ZWIERCIADLANE CZY ZŁUDZENIE OPTYCZNE? - RZECZ O KILKU STRATEGIACH W TEUMACZENIACH TEKSTÓW LITERACKICH Z JĘZYKÓW POLSKIEGO I HISZPAŃSKIEGO NA JĘZYK WŁOSKI
}

DOI: http://dx.doi.org/10.12775/RP.2015.002

\begin{abstract}
Zarys treści: W artykule poruszono problemy dotyczące strategii tłumaczeniowych, które obejmują utwory polskich i hiszpańskich autorów należących do kręgu dwóch odmiennych kultur: Europy Środkowo-Wschodniej (Konopnicka i Iwaszkiewicz) i Ameryki Łacińskiej (Cortázar, Rulfo i Carpentier), spostrzegane przez pryzmat języka i kultury włoskiej. Wybór autorów i utworów nie jest przypadkowy, gdyż z jednej strony dla polskich pisarzy Włochy stały się intelektualną i antropologiczną przygodą, krajem oscylującym między realizmem a fantazją, z drugiej zaś elementy należące do nurtu hiszpańskojęzycznego realizmu magicznego znajdują odbicie w nowych przekładach literackich w języku włoskim, scalając i oddalając kultury dwóch kontynentów. Zastosowane strategie/chwyty tłumaczeniowe egzemplifikują to, co może stanowić novum i continuum w zakresie dzisiejszego przekładoznawstwa.
\end{abstract}

Słowa kluczowe: strategie tłumaczeniowe, przekład literacki, przekładoznawstwo

W Polsce na przestrzeni XX stulecia naukowe badania translatorskie dotyczyły głównie zainteresowań i potrzeb polskiego czytelnika. Sama wiedza na temat mało znanej obcej literatury ograniczała się do kilku prac naukowych i tłumaczeń, drobnych artykułów prasowych oraz pobieżnych analiz tekstów. W ciągu ostatnich trzydziestu lat sytuacja uległa gruntownej zmianie. Dziś obserwujemy łatwiejszy dostęp do publikacji obcojęzycznych, obcej krytyki literackiej i teatralnej, które wzbogacają i udoskonalają narzędzia metodologiczne w konceptualizacji materii badawczej. Dość staranny przegląd 
myśli teoretycznej na temat przekładoznawstwa znajduje odbicie we współczesnych polskich pracach naukowych ${ }^{1}$, które są opatrzone w szczegółowe komentarze i wzbogacone w liczne przykłady zaczerpnięte $\mathrm{z}$ obcej literatury pięknej, poezji i dramatu.

We Włoszech duże zainteresowanie dwudziestowieczną polską i hiszpańskojęzyczną literaturą i poezją stało się punktem wyjścia do eksploracji nowego terenu badawczego przez polskich i włoskich tłumaczy-pracowników nauki. Dlatego w niniejszym artykule odwołano się do użycia kilku technik, czyli tzw. strategii tłumaczeniowych z języka polskiego (A - język wyjściowy) na włoski (B - docelowy) oraz języka hiszpańskiego (A - język wyjściowy) na włoski (B - docelowy). Czy są to tłumaczenia dalece odbiegające od oryginału i czy przybliżą nieznany świat czytelnikowi? Kim tak naprawdę ma stać się tłumacz w nowym stuleciu: czy ma podążać śladami Kolumba, poszukując nowych środków ekspresji, nowych sposobów i technik, aby wyrazić i przekazać myśli autora, czy też nowy tekst będzie „żywą maską” - kalką tego, co pragnął ukazać autor? A może oryginał stanie się „auto-tekstem” tłumacza? Zdajemy sobie sprawę, że wiele rzeczy jest nieprzetłumaczalnych na język - „pomyślmy o snach czy intuicji, dzięki której można odgadnąć prawdziwe znaczenie słów. Ale tylko oryginalne brzmienie... lub lokalny koloryt może... Niewypowiedziane słowa. Niemy język. Nieznana przygoda”. Wyimaginowany świat lub nowy krajobraz Meksyku (Rulfo 1994: 28) - mogą oddać ducha i nadać właściwy sens przełożonemu tekstowi. W ten sposób Juan Rulfo, meksykański powieściopisarz, we wstępie do znanej powieści $P e$ dro Páramo, zwraca uwagę potencjalnego odbiorcy na problemy wynikające z nieprzetłumaczalności tekstu literackiego na język obcy. Autor podkreśla, że w tłumaczeniu należy ograniczyć do minimum nieprzetłumaczalne frazy lub wyrażenia, zachować oryginalne brzmienie, postaci, ich entourage, nawet lokalną atmosferę, a w szczególności egzotyczny meksykański świat fauny i flory, który staje się magicznym miejscem dla europejskiego czytelnika. Wynikające z tego tytułu strategie tłumaczeniowe są na tyle trudne, że w niniejszej pracy obejmują utwory polskich i hiszpańskich autorów należących do kręgu dwóch odmiennych kultur, łączących kraje Europy Środkowo-Wschodniej (Konopnicka i Iwaszkiewicz) i Ameryki Łacińskiej (Cortázar, Rulfo i Carpentier), a więc Polski, Argentyny, Meksyku i Kuby; są to kraje zróżnicowane pod względem lingwistycznym, kulturowym, konceptualnym,

${ }^{1}$ Są to kompendia wiedzy na temat teorii i zastosowanych technik w przekładoznawstwie, które zawierają interesujące wnioski dotyczące aplikacji teorii przekładu w analizach różnych rodzajów tekstów. 
a tutaj spostrzegane przez pryzmat języka i kultury włoskiej. Wydać się może oczywiste, że nic nie zadziwi czytelnika w przytoczonych nazwiskach autorów znanych, cenionych i tłumaczonych na wiele języków obcych. Jednak tłumacz wciąż może go zaskakiwać swoją inwencją, odświeżonym przekazem i stylem, komizmem i dowcipem, samą grą słów i sposobem przedstawionej narracji. Dlatego wybór poszczególnych autorów i utworów nie jest przypadkowy. Z jednej strony dla polskich pisarzy magiczny kraj - Włochy stał się nie tylko źródłem inspiracji, ale intelektualną przygodą antropologiczną, krajem oscylującym pomiędzy realizmem a fantazją; z drugiej strony zaś istotne elementy tworzące tzw. nurt realizmu magicznego, w wymiarze krajów hiszpańskojęzycznych Ameryki Łacińskiej, znajdują odbicie w nowych przekładach literackich w języku włoskim, scalając lub też oddalając dwie kultury, dwa kontynenty. Zastosowane tutaj strategie/chwyty tłumaczeniowe nie stanowią recepty jednorazowego użytku, ale są egzemplifikacją tego, co może być novum i continuum w zakresie dzisiejszego przekładoznawstwa.

A oto kilka uwag i spostrzeżeń na temat pozornej łatwości translacji na przykładzie wybranych fragmentów włoskiej poezji Marii Konopnickiej (Konopnicka 1919: 61; Konopnicka 2012: 204) wybranych sycylijskich opowiadań Jarosława Iwaszkiewicza (Iwaszkiewicz 2012: 101). Motyw podróży i podróżowania stał się jednym z dominujących tematów w literaturze światowej. Włochy to piękny kraj Europy Południowej, który jest jednocześnie zróżnicowany pod względem językowym, kulturowym i gospodarczym. Polscy podróżnicy, przemierzając całą Italię, zdali sobie sprawę z faktu, że każdy region we Włoszech stanowi odrębną mozaikę językową i kulturową. Dlatego w każdym regionie słyszy się inny dialekt, próbuje się oryginalnych potraw i spotyka ciekawych ludzi. Na samym początku podróżnicy mieli wrażenie, że znajdują się gdzieś na odległej, obcej planecie, którą wielokrotnie Iwaszkiewicz nazywał „wyspą szczęśliwości”. Ale czy tak jest naprawdę? Czy niewidzialna granica oscylująca pomiędzy magicznym światem a codziennymi realiami może zatrzeć się całkowicie, a zwykła codzienność może stać się mitycznym dniem? Jak ten fenomen odbierali polscy podróżnicy końca XIX i XX stulecia: Maria Konopnicka i Jarosław Iwaszkiewicz.

Zaraz po zakończeniu I wojny światowej, w 1919 roku, ukazało się drukiem mediolańskiej oficyny tłumaczenie tomiku poezji Marii Konopnickiej z 1901 roku pt. Italia. We wstępie Ettore Cozzini podkreślał znaczenie poezji „polskiej męczennicy” na tle europejskiej liryki oraz ogromne wyzwanie, przed którym stanął tłumacz - Mattia Loret. Tłumacz pragnął zaproponować włoskiemu czytelnikowi lekturę nieznanej polskiej poezji o charakterze patriotyczno-narodowo-wyzwoleńczym, która powstała pod wpływem skom- 
plikowanej sytuacji geopolitycznej Polski. Zbiór Italia, liczący około 20 utworów, staje się nowym spojrzeniem na świat i człowieka. Konopnicka, stosując określone motywy liryczne i historyczne, zaczerpnięte głównie z włoskiego malarstwa (kształty i kolory zmieniające się zależnie od pory dnia, roku i regionu Włoch), kreuje włoski świat ulotnych nastrojów, emocji, dźwięków i obrazów. Dlatego włoski tłumacz stosownie wybiera i miesza liczne pieśni Konopnickiej o charakterze lirycznym, łącząc je we wspólną całość, nadając im wspólną nazwę Italia. Kompozycja nowej Italii we włoskim tłumaczeniu wydaje się uporządkowana i uszeregowana, jednak nie stanowi koherentnej całości przemyśleń poetki pod względem tematycznym i filozoficznym; jedynie jest mieszanką uczuć, wielonastrojowym potpourri utworów-pieśni o charakterze lirycznym. Utworem otwierającym tomik jest Inwokacja - Invocazione sulle soglie d'Italia, której towarzyszą dwa inne: Ranek $w$ Wenecji - Mattinata a Venezia i Incanto, czyli - Unaltra mattinata a Venezia. Tłumacz trafnie w pierwszym utworze przedstawia długą i bolesną drogę poetki jako „wędrowcy, pątnika” (u Konopnickiej), pellegrino - 'pielgrzyma' (u Loreta), którą musi przemierzyć, aby dostrzec i znaleźć się „na tym brzegu zbawionym” - a questa riva liberata. To właśnie tutaj, we Włoszech „Morze, słońce, ogromne duchy i ruiny, Mają tu nieśmiertelne i królewskie trony" - Il mare, il sole, gli spiriti giganti e le rovine, Hanno qui immortali e regali troni.

W lirycznym dialogu i opisach przyrody rozwija się wiele obrazów należących do świata wewnętrznego, pełniącego funkcję emotywną, jak w Grande Scoglio, Adwokacja - Evocazione, i świata zewnętrznego (morze, cztery żywioły wojujące ze sobą - burza, ogień, wiatr i ziemia), jak w Mare morto, Mewy - Gabbiani, czy w Incanto, aby w ostatnich utworach położyć akcent na oczekiwanym i wymarzonym dniu wolności, który nadejdzie i przyniesie zjednoczenie całej Italii, m.in. w Grande Scoglio:

Burzliwa noc wiosenna. Huk na morzu głuchy [...]

Una notte di primavera tempestosa. Sul mare una romba cupa [...]

Trzeszczą skały smagane wściekłymi wybuchy [...]

Cresciano le rupi percosse dalle rabbiose fiancate [...]

Wtem złota błyskawica szeroko zaświeci...

Ecco, e un lampo d'oro avvampa vastamente

Tam, u Garan Scoglio, czy to gromadzą się duchy? [...]

Lì, presso il grande scoglio, s'adunano spiriti? [...]

Zaszumiały w nadbrzeżnym ogrojcu oliwy...

Sussurrano gli ulivi nelle ulivete della costa... 
Żwir skrzypnął... Wódz-że duchów to, czy człowiek żywy,

La ghiaia cricchia...forse un duce d'anime o un uomo vivo,

Nakryty nocą, orłem $w$ świat runął ze skały? [...]

ravviluppato dalla notte, aquila, rovina verso il mondo dallo scoglio?

Italio! Twojej jedności grom bije i chwały! (Konopnicka 2012: 194)

Italia! Della tua unità il fulmine e della tue gloria (Konopnicka 1919: 24-25).

Należy podkreślić, że tłumaczenie stanowi patetyczną próbę przejścia od zmysłowej rzeczywistości, skupiającej się na określonych bodźcach i wrażeniach wzrokowych, m.in. „huk na morzu, słychać trzask zawieruchy, grom bije i chwały", do autorefleksji, czyli wewnętrznego spojrzenia na elementy morskiego pejzażu, które są waloryzowane i estetyzują heroiczny czyn żołnierza - Garibaldiego. W zaznaczonych fragmentach obserwujemy wyraźne różnice pomiędzy tekstem oryginału a przekładem o charakterze ideologicznym, które sprowadza się do częściowej zmiany treści utworu; uwypukla się więc dystans pomiędzy ,ja” lirycznym a opisywaną przez tłumacza osobą wodzem narodu - duce. Trzeba podkreślić, że już w 1919 roku bardzo modne było określenie duce, które odnosiło się do Mussoliniego, założyciela partii „czarnych koszul”; użycie określenia duce - wódz kontrastuje więc z Garibaldim jako wodzem wszystkich Włochów z okresu zjednoczenia; dlatego zastosowanie wyrażenia duce - wódz sprawujący rządy nad duszami żywych i umarłych staje się pompatyczne i nieco śmieszne. Nawet ostatnie wersy nie urzekają naturalnością, np. „runąć” - rovinare, a sam tłumacz popada w banał, zapominając o intencjach Konopnickiej. Czujemy zatem tzw. zgrzyt poetycki, który może świadczyć o pewnej tendencji w ówczesnej poetyce przekładu. Kluczowa w przekładzie winna stać się zwięzła forma pieśni i sposób spostrzegania nowego wizerunku świata. Immanentną cechą poetyki Marii Konopnickiej jest urzekająca zwięzłość i melodyjność, która nadaje całej strofie swoiste brzmienie. Konopnicka ubiera myśli w proste słowa, a zastosowanie nowej strategii w tłumaczeniu, polegającej na nadinterpretacji testu poetyckiego, wnosi nadwyżkę znaczenia przekazu poetki. Włoski tłumacz odwołuje się do tzw. elementów nacechowanych stylistycznie, nieoczekiwanie zmienia użycie czasowników, np. stendersi/distendersi - 'rozlać się w Mare morto, czy wielkich liter, stosuje stylizację archaiczną lub leksykalne archaizmy, które wprowadzają odbiorcę w patetyczny nastój.

[...] Wnet ty, o najsrebrzyste, ty, o wniebowzięte,

Z krzykiem żądzy nań spadasz i zwierzęcą twarzą (Konopnicka 2012: 186).

[...] subito tu, tutto d'argento, tu, estatico in cielo, 
col grido della brama, ti precipiti, e con visto di belva [...]. (Konopnicka 1919: 30-31)

A więc rozlej się za mną, morze zapomnienia...

Tu ti stendi dientro di me, mare dell'oblio...

A więc opłyń mnie w koło wodami cichymi...

Mi avvolgi con le tue acque tranquille....

Niechaj nikt, nigdy, w żadnym zakątku tej ziemi

perchè nessuno mai in nessun angolo di questa terra

Nie szuka okiem mego cienia!

cerchi con l'occhio la mia ombra fugace! [...]

Ciszy chcę! Do wiecznego tęskno mi spocznienia.

Io desidero la pace, desidero la requie sempiterna.

[...] A ty się rozlej za mną, morze zapomnienia! (Konopnicka 2012: 198)

E tu, mare d'oblio, distenditi dietro di me! (Konopnicka 1919: 31-32).

Trzeba przyznać, że forma pieśni w Italii wiąże słowo i podkreśla muzyczność całej strofy utworu. Italia staje się sygnałem odsyłającym do polifonicznej przestrzeni pomiędzy warstwą słowną a muzycznością rymów. W przekładzie warstwa brzmieniowa pieśni traci na wartości. Tłumacz zapomniał o umiejętnie stosowanych powtórzeniach, o efektach fonicznych, o zastosowaniu powtórzeń; dlatego sam przekaz nowego tekstu nieco zubożał. Konopnicka sięga do wiersza jedenastozgłoskowego, w Italii zaś ulubionym metrum staje się trzynastozgłoskowiec. Tłumacz nadmiernie rozbudowuje i wydłuża oryginalne brzmienie, tracąc w ten sposób rytm; zastosowanie luźniejszej weryfikacji ma uwydatnić obrazową jakość oryginału, jednak użycie określonej strategii tłumaczeniowej mija się z celem. Inne liryki w tłumaczonej Italii nieco wykraczają poza metaforyczne pojęcie wolności czy wiecznej szczęśliwości. Odzwierciedlają stan ducha i psychiki podmiotu lirycznego, budząc pewne skojarzenia z cierpieniem poetki. Pozostałe liryki zaś w tłumaczeniu naznaczone są bólem, tak jak w Madonnach i Sykstynie.

Iwaszkiewicz pisze o Włoszech i o Sycylii jako literat, esteta, historyk i podróżnik, dokumentalista, cudzoziemiec, stały bywalec południowej wyspy słońca:

[...] Toteż zaczęło się od tego, żeśmy z panią Cannet połączyli nasze stoliki; przystąpiliśmy do opowiadań o naszych wrażeniach z Sycylii: ona kończyła podróż, ja dopiero zaczynałem, opowiadała mi więc o rzeczach, jakie nie wchodzą do drukowanych przewodników. Przy tym ona znała znakomicie ów tajemniczy, dziwaczny 
i kochany kraj i wprowadzała mnie po trosze w świat świątyń, pszenicy i błękitnego nieba (Iwaszkiewicz: 1994: 242).

Così decidemmo con la signora Cannet di legare i nostri tavoli insieme; ognuno di noi cominciò a raccontare le sue storie ed esprimere le proprie impressioni sulla Sicilia: ella finiva il suo viaggio ed io lo aveva appena cominciato. La signora mi raccontava tutto quello che non si sarebbe potuto travare in nessun guida. Ma, ad un tratto, lei cominciò a svelare i segreti dell'incantato ma strano paese e, passo dopo passo, mi metteva in contatto diretto col mondo siculo e con le sue bellezze naturali, quali i campi di grano, il mare azzurro ed i templi (Iwaszkiewicz 2012: 20).

Perspektywy te mieszają się ze sobą, tworząc oryginalną syntezę wiedzy o mieszkańcach i czasach, które co prawda przeminęły, ale pozostaną na wieki zapisane na kartach powieści i nowel. Dzięki temu możemy skonfrontować wizerunek wczorajszej i dzisiejszej Sycylii.

[...] Czerwone koniczyny na polach - na południu - samotne świątynie, wesela sycylijskie, wozy malowane w kolorowe obrazy romantycznej przeszłość, marionetki grywające dramaty o tematach zaczerpniętych z legend Karola Wielkiego - wszystko było dobre, aby poruszyć nasz entuzjazm i wzbudzić zainteresowanie zakochanych Amerykanów (Iwaszkiewicz 1994: 259).

[...] Con grande entusiasmo ci riferivamo alla descrizione del paesaggio, ai quadrifogli rossi cresciuti sul prato - nella parte meridionale dell'isola - e ai templi abbandonati, alle nozze siciliane, ai carrelli dipinti di vari colori che rapresentavano le storie romantiche e sentimentali del passato, ai pupi siciliani che recitavano i drammi le cui azioni risalivano ai tempi del Grande Carlo Magno - tutto era affascinante e serviva per suscitare l'attenzione dei due innamorati Americani (Iwaszkiewicz 2012: 44).

Magia zakątka starego kontynentu, wyśmienita kuchnia, palące słońce i przezroczyste morze - to zbudza zachwyt zarówno polskiego, jak i włoskiego czytelnika, ich zainteresowanie malowniczą i zarazem tajemniczą Sycylią. Sycylia w dwóch włoskich nowelkach Iwaszkiewicza: Powrót Prozerpiny i Hotel Minerwa staje się miejscem, w którym mitologia przeplata się z rzeczywistością dnia codziennego; jest idealną enklawą dla zakochanych, nową ziemia obiecaną, pełną egzotycznej przyrody, zapachów i woni kwitnących kwiatów unoszącej się we wszystkich zakątkach tej wyspy.

Dwie włoskie nowelki Iwaszkiewicza po raz pierwszy przetłumaczone na język włoski są egzemplifikacją tłumaczenia (między)kulturowego, przy 
zachowaniu sycylijskich norm kulturowych, morfosyntaksy i ekwiwalentów stylistyczno-leksykalnych. Tłumacz, jak przypomina Umberto Eco (Eco 2003: 162), nie powinien brać pod uwagę tylko reguł gramatycznych, w sensie dosłownym, ale musi skupić się na elementach należących do tzw. transferu kulturowego. Interesujące jest podkreślenie roli tłumacza i jego funkcji jako mediatora-pośrednika wielokulturowego. Zastosowanie w przypadku tłumaczenia asymilacji kulturowej dotyczy obserwacji tego procesu na poziomie (prze)tłumaczonego tekstu, ale w zupełnie innym wymiarze kulturowym. Do tej kategorii zaliczamy elementy należące do sfery tradycji, zwyczajów, nazw własnych, tytułów i cytatów literackich, historii, malarstwa, muzyki itp. danego obszaru kulturowego. Dlatego analiza wybranych utworów Iwaszkiewicza w kategoriach przekładu kulturowego ma charakter wielowymiarowy. Kluczowa w przekładzie jest zwięzłość i oddanie wzrokowej, rzec można migawkowej, fotograficznej percepcji sycylijskiego krajobrazu, ukazanego w opisie wody i lądu, gór i miasta - Palermo. Nadrzędne role odgrywają kolorystyka pejzażu, opis stanu ducha protagonistów oraz opis ikonicznego braku czasu i nadmiaru czasu w odpowiednio zwięzłej formie:

[...] Dla zabicia czasu i nudy, która mnie zaczynała osaczać, pojechaliśmy tramwajem do Monreale (Iwaszkiewicz 1994: 274)

[...] Per non avvertire la noia che mi aveva invaso e per far passare il tempo, non restava che prendere un tram per andare a Monreale (Iwaszkiewicz 2012: 63-64).

Chwilami tłumacz odwołuje się do kilku strategii wyborów tłumaczeniowych: 1) naturalizacji - dosłownego zapożyczenia słowa i pisowni w języku docelowym: [...] A właśnie wtedy nadeszła epoka owego paskudnego - il greco / Proprio in quel momento arrivò la stagione del tremendo - scirocco; 2) transpozycji - zastąpienia wyrazu innym wyrazem, charakterystycznym dla kultury sycylijskiej i włoskiej: [...] Na zawsze - zaśmiał się - co to znaczy na zawsze? A może takie dwa miesiące wyrwane z paszczęki lwa lepsze są niż „na zawsze”? / Per sempre? - sorrise - che significa per sempre? Forse non è meglio passare due mesi da leone che vivere "per sempre" dei giorni da pecora?; 3) modulacji, czyli przekształcenia zwrotu i zastąpienia go innym w języku docelowym: [...] Chleb smakuje tylko podzielony z inną ludzką stroną/ È vero che il pane diventa più saporito nel momento in cui va diviso con un'altra persona; [...] Dlaczego ludzie się kochają? Dlatego, jak mówi nauczyciel Dyndały, że jest w nich siła „usypiatywna”, czyli „,kochatywna”... czy nie uważa pan, że siła „kochatywna” jest niesprawiedliwie podzielona między ludźmi? / Perché le persone si amano? Ma visto che dorme in 
loro una grande forza „contemplativa”, ossia , attiva” - come avrebbe detto uno dei filosofi di Candido - si amano così. Ė vero, però non pensa cha la cosiddetta forza „amativa” sia divisa in modo ingiusto tra la gente?; [...] zabawa się podobała, zmieniono tancerzy co chwila / il "gioco delle parti” piacque a tutti coloro che vovlevano cambiare i propri compagni di danza; 4) ekwiwalentu idiomatycznego lub kulturowego, użytego m.in. w imionach własnych, nazwach dzielnic i ulic itp.: [...] widziałem, że się bał. Strasznie się

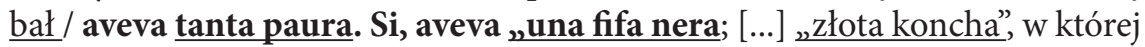
śpi ta perła / [... ${ }_{2}$ conca d'oro” in cui dormiva tutta la città di Palermo”.

Przy użyciu odpowiednich strategii tłumaczeniowych i zastosowaniu transferu kulturowego, tekst staje się istotnym nośnikiem informacji. Tłumaczenie międzykulturowe implikuje więc użycie „kulturemu”, czyli tzw. konceptualnego zbioru kluczowych słów, symboli i elementów werbalnych, niewerbalnych i parawerbalnych w tekście docelowym; dzięki ich zastosowaniu możemy zaobserwować w (prze)tłumaczonym tekście specyfikę dwóch różnych kultur: polskiej i włoskiej.

[...] Pewna nuta niepokoju narzucała matowy ton jego pytaniom, pewna nieuchwytna zmarszczka cierpienia przecinała jego wysokie, białe czoło. Interesował mnie ów ton, niby głęboki dźwięk, którego nabierają pęknięte skrzypce; ton, który był zawsze czymś najbardziej obcym u wszystkich spotykanych przez mnie Amerykanów. Jednocześnie zauważyłem, że cierpienie, owe półtony żalu brzmiące w głosie Dicka, owo zniechęcenie widoczne w gestach jego wyniosłej postaci - było czymś obcym jego naturze [...] (Iwaszkiewicz 1994: 245-246).

Tuttavia il timbro inquietante della sua voce imponeva alla conversazione un tono opaco; e mentre parlava passò un segno indefinibile di sofferenza sull'alta e carnosa fronte del suo volto. Mi piaceva il timbro basso e profondo della sua voce che assomigliava quasi ad un violino scordato; il suo tono divenne il più strano che avessi mai sentito usare da un americano. Ad un tratto mi pareve che una sofferenza e un immenso rimpianto dell'anima risuonassero molto forte nella voce di Dick, pur essendo egli di alta statura; i gesti esprimevano uno stato d'animo di dipressione che, per dira la verità, in realtà non si addiceva alla sua vera natura (Iwaszkiewicz 2012: 25-26).

Cała translacja odpowiada naturalnemu i uwspółcześnionemu językowi włoskiemu. Dlatego zwrócono uwagę na zastosowanie niuansów w przekładzie, które nie powodują dysonansu stylistycznego, a wywołują czasami efekty komiczne, farsowo-komiczne, nawet groteskowe; odpowiadają więc treści oryginalnej noweli i podkreślają dualizm natury człowieka. Dokonując trans- 
lacji wybranych nowel Iwaszkiewicza, tłumacz starał się zachować zmiany na różnych poziomach tekstu, które nie prowadziłyby do całkowitej adaptacji, lecz do poprawnej translacji, po to, aby tekst (prze)tłumaczony stał się jasny, koherentny i zrozumiały przez obcego odbiorcę oraz zachował melodię i oddał klimat sycylijskości w języku włoskim.

Włoska poetyka realizmu magicznego - Bontepellego, Savinia i Landolfiego, znalazła swoje odzwierciedlenie w hiszpańskojęzycznej literaturze krajów Ameryki Łacińskiej. Utwory takich pisarzy jak Borgesa i Cortázara (Argentyna), Marqueza (Kolumbia), Carpentiera (Kuba) i Rulfa (Meksyk) egzemplifikują, nadają nowy ton i określają oryginalny kanon w literaturze światowej pod znakiem odrodzonego i zmodyfikowanego hiszpańskojęzycznego realizmu magicznego. Dlatego pomost literacki pomiędzy Europą - Włochami a Ameryką Łacińską - Argentyną i Meksykiem tworzy syntonię i łączy we wspólną całość włoską surrealistyczną magię z komponentami wierzeń, tradycji i egzotyki krajów hiszpańskojęzycznych. Pisarze hiszpańskojęzyczni odwołują się w swoich szkicach, opowiadaniach i powieściach do definicji poetyki realizmu magicznego Massima Bontempellego. Stanowi ona rodzaj połączenia fantazji z rzeczywistością, gdzie "prawdziwą normą pisarstwa jest przywołanie snu, który staje się realnością, a rzeczywistość właśnie snem" (Bontempelli 1974: 316). Nowa koncepcja realizmu magicznego postrzeganego jako realizm fantastyczno-psychologiczny (Yurkievich 1984: 12-16) oscyluje między magią świata Ameryki Łacińskiej a Europą i znajduje swoje odbicie w twórczości argentyńskiego pisarza Julia Cortázara. W świetle poetyki realizmu magicznego Cortázar, podobnie jak jego europejscy prekursorzy, proponuje zastosować realną i prawdziwą historię, którą pragnie rozwinąć za pośrednictwem magicznej i metaforycznej akcji, deformując formę wypowiedzi, żonglując słowami, używając neologizmów, bogatego i zróżnicowanego pola leksykalno-semantycznego; pisarz zmienia rejestry językowe, aby przekazać czytelnikowi alegoryczno-symboliczny obraz świata. Dlatego przymiotnik "magiczny” wskazuje czytelnikom połączenie fantazji z rzeczywistością, z nieuchwytną realnością, której nie jesteśmy w stanie zinterpretować przez logikę zmysłów, a czasem nawet i słów. Wyraźną egzemplifikacją wariantu realizmu magicznego może stać się próba (prze)tłumaczenia opowiadania Cortázara pod tytułem Deshoras - „a deshora?”, Disincontri (Cortázar 1994: 1-2), w języku włoskim 'nieoczekiwanie/a', a w tłumaczeniu polskim - Niewpory (Cortázar 1989: 2-4). Tłumaczka włoska Cecilia Rizzotti usiłowała oddać oryginalną wersję brzmieniową tytułu, co stanowiło ogromną trudność. W języku włoskim disincontri oznaczają w języku hiszpańskim desencuentros, a więc nieoczekiwane spotkania. Została zachowana zbieżność 
pierwszej litery w tytule opowiadania w języku wyjściowym i docelowym, ale tłumaczka zapomniała zachować choćby częściową zgodność brzmieniową tytułu:

Antes de que se fuera, y ahora que llenaría mi recuerdo durante muchos dias, [...], decidí no perder un momento más// Prima che se andasse, e ora che poteva già nutrire il mio ricordo per molti giorni, [...], decisi di non perdere neppure un minuto più.

W perspektywie czasowej subtelna modulacja samogłoskowa pomiędzy ahora i ora - 'teraz' oraz momento/minuto - 'chwila/ułamek sekundy' powinna odnieść się do rzeczywistości, do danej chwili; dlatego każda drobna zmiana wprowadzona przez tłumacza na poziomie makrotekstu w języku docelowym może grozić ryzykiem utraty właściwego znaczenia i sensu w języku wyjściowym. Warto podkreślić, że u Cortázara sposób wypowiedzi i narracji jest osobisty, egzystencjalny, oparty na wspomnieniach, autobiografii i wewnętrznych przeżyciach. Pisarz podąża w kierunku antropologii człowieka, która z jednej strony staje się wyraźnym potwierdzeniem tego, co się dzieje w jego umyśle i duszy, z drugiej strony zaś eksploruje „antropologiczne pisanie" (Ph. Lejeune, C. Bogaet 2005: 5) jako sposób na życia, które jest rodzajem „autoterapii” duchowej, ucieczki od upolitycznionej i inwigilowanej szarej rzeczywistości w wewnętrzny lub magiczny świat argentyńskiej przyrody. Dlatego Cortázar utożsamia się z prostym człowiekiem, który jest w stanie zrozumieć jego alienację. Wypowiedzi są fragmentaryczne, enigmatyczne, zdawkowe i napełnione dużym ładunkiem emocjonalnym, co może oddać dramatyzm i niepewność sytuacji, stan ducha bohaterów związany z nicością i inercją, np. relacje pomiędzy Sarą, Dorem i Annibalem w Niewporach, czy fragmenty odwołujące się do filozoficznej koncepcji istnienia w Pisząc opowiadanie J. Derridy. Przez użycie kilku zwrotów podniosłych i wyrażeń idiomatycznych tragizm zmienia się w komizm sytuacji, a płacz w śmiech. Są to chwyty zastosowane przez włoskich tłumaczy, które wprowadzają czytelnika w rejestr językowy fenomenologii - staje się on projekcją wewnętrznego świata bohaterów, natomiast przestawny szyk, liczne aluzje symboliczne i alegoryczne, metafory i peryfrazy starają się oddać ducha oryginału włoskiego przekładu.

Dla polskiego czytelnika magiczny świat meksykańskiego pisarza Juana Rulfa jest nieco zapomniany. We Włoszech natomiast jego powieści Pedro Páramo i Równina w ogniu doczekały się kilku przekładów (Rulfo 2012: 2-8). Sam pomysł narracyjny pierwszej powieści, kilkakrotnie tłumaczonej na ję- 
zyk włoski, opiera się na schemacie podróży, tzw. inter romanum, głównego bohatera - Juana Preciada, który pragnie po śmierci matki wypełnić jej ostatnią wolę. Udaje się więc w pełną zagadek podróż do nowej dantejskiej „piekielnej krainy" - Comala, w poszukiwaniu własnej tożsamości i nieznanego ojca - Pedra Páramo.

Dlatego opisy nieznanego i tajemniczego miasta, sąsiedztwa i otoczenia (równiny, góry i pagórki) urzekają poprawnością i naturalnością, odczuwa się „świeży” powiew poetyckiego tchnienia pisarza meksykańskiego.

Tłumaczenie na język włoski Rulfa zachowuje prawie całkowite struktury morfosyntaksy języka oryginału. Natomiast intencję ostatniego tłumaczenia Paola Colli było oddanie onirycznego charakteru oryginalnego tekstu:

[...] Parecía que me hubiera estado esperando [...] una mujer como si no existiera/ Sembrava che stesse aspettendo [...] una donna come unombra (1)/Pareva che mi stesse aspettando $[\ldots]$ una donna come se non fosse esistita (2).

Zastosowanie w cytowanym przekładzie dwóch funkcjonalnych ekwiwalentów w języku włoskim: 'un'ombra', cienia i 'non fosse esistita', czyli procesu rozmycia się osoby w czasie i przestrzeni, wyraża czynność możliwą w teraźniejszości lub najbliższej przyszłości albo tę, której spełnienie jest mało prawdopodobne. Egzystencja głównego bohatera oscyluje pomiędzy snem a jawą, światem rzeczywistym a wyimaginowanym, życiem a śmiercią i sprowadza się do jednego wymiaru: onirycznej rzeczywistości. Nieprzetłumaczalna gra słów, transpozycja, dwuznaczne użycie wyrażeń idiomatycznych, przedłużanie zdań za pomocą dłuższych, opisowych słów, szyk przestawny wiąże się $z$ odejściem od tekstu oryginału, możemy więc odczuć niedosyt, ambiwalencję wypowiedzi, a nawet pewną obcości w tekście języka docelowego, np. [...] Bonita fiesta le va a armar/Sarà una bella sorpresa per lui/Che bella festa le starà preparando. Jednak nie zmienia to sensu translacji całego tekstu.

Zaskakujący jest fakt, że już od samego początku włoscy tłumacze borykają się ze związkami przyczynowo-skutkowymi występującymi na płaszczyźnie temporalnej i przestrzennej. Dla tłumacza stanowi to ogromne wyzwanie, a nakładanie się i wzajemne przenikanie sfery czasowej i przestrzennej może wprowadzić nielogiczność $\mathrm{w}$ dalszej narracji lub nawet przyczynić się do zakłóceń w samym przekazie:

[...] Me estuve allí esperando, hasta que al fin apareció este hombre/ Me ne stavo lí indeciso sulla direzione da prendere, quando finalmente era apparso quell'uomo (1)/ Io stavo lí ad aspettarre, fino a quando apparve quest'uomo (2). 
Tłumacze wzięli pod uwagę fakt, że język poetycki Rulfa jest bardzo oszczędny w środki wyrazu. W koherentnym opisie postaci i krajobrazu starali się podkreślić interferencję pomiędzy tym, co odczuwa Juan, i opisem przyrody. Niewątpliwą wagę odgrywa tutaj użycie właściwej formy czasownika esperar-sperare/aspettetare 'czekać/oczekiwać' lub zupełne pominięcie tego czasownika. Cechą charakterystyczną języka hiszpańskiego w Ameryce Łacińskiej jest stosowanie formy czasu przeszłego nieokreślonego, co w oryginale może służyć do zaakcentowania grozy, niepewności, tajemniczości oraz może wpłynąć na dynamikę rozwoju akcji opowiadania. Zastosowanie takiej konstrukcji w języku włoskim byłoby niezręczne gramatycznie. Dlatego użycie w wersji docelowej czasu przeszłego niedokonanego wyrażonego czasownikiem aspettare i czasu zaprzeszłego apparire 'pojawiać się' stwarza atmosferę charakterystyczną dla opisów tła, krajobrazu, nastrojów lub osób, relacjonuje także wydarzenia, które $\mathrm{w}$ tym ujęciu stanowią pewien rodzaj kontinuum akcji powieści, a nie podkreślają jej finału. Przetłumaczone na język włoski struktury gramatyczne uległy nieco zmianie, ale bez poważnych konsekwencji dla semantyki całego tekstu, zubożając w niewielkim stopniu oryginalną warstwę brzmieniową. W wersji wyjściowej i docelowej Pedro Páramo obserwujemy ciągłą zmianę ruchu (ze statyki w dynamikę) i miejsca, która jest związana z symultanicznym wymiarem czasowo-przestrzennym. Motorem działania jest czasownik - vivir 'żyć' i esistir 'istnieć. Dlatego akcja utworu „nabiera intensywności wtedy, gdy łączy różne tematy ze sobą, zaś słowa - koncepty tworzą zmieniające się figury zgodnie ze zmiennymi szybkościami lektury oraz jej skojarzeniem". Biorąc pod uwagę cytowane słowa Deleuse’a (Deluese 1972: 2-6), powieść Rulfa może wywodzić się ze wcześniejszych przesłanek stroboskopicznych. Sam termin "ruch stroboskopowy” zastosował po raz pierwszy, w latach 70. XX wieku, francuski filozof Gilles Deleuse. Od samego początku akcja powieści Rulfa w wersji oryginalnej i tłumaczeniowej (ostatnie tłumaczenie) nabiera niezwykłej szybkości, a nawet trudno ją powstrzymać. To tutaj, hic et hunc, historia miesza się z teraźniejszością i dotyka przeszłości i przyszłości, a sposób przedstawiania rzeczywistości w staje się niejako na nowo obudzoną rzeką Heraklita. Jej nurt nabiera niezwykłej szybkości. Cały świat oscyluje między realnością a chwilową nirwaną, złudą a zapomnieniem, życiem a śmiercią.

Pozostańmy w kręgu realizmu magicznego, ale tym razem kubańskiego autora Alejo Carpentiera. Kuba kojarzy nam się z cudowną, inspirującą wyspą słońca, na której mamy wrażenie, że panuje niekończący się mityczny czas. Ale Kuba to nie tylko gorąca wyspa, tryskająca energią witalną niczym wulkan, to egzotyczny świat fauny i flory, orzeźwiających napojów i smako- 
witych potraw. Dlatego powieści i opowiadania Carpentiera są cenione wśród europejskich znawców literatury pięknej. W Europie przetłumaczono kilka opowiadań i powieści tego autora, ale we Włoszech pozostaną na długo w pamięci opowiadanie Podróż do źródeł czasu i powieść Królestwo z tego świata, należące do nurtu hiszpańskojęzycznego realizmu magicznego.

Skoncentrujmy uwagę na pierwszym opowiadaniu, kilkakrotnie przetłumaczonym na język włoski. We włoskich strategiach tłumaczeniowych warstwa językowa i leksykalna zajmuje najważniejsze miejsce. Warstwa językowa dotyczy poziomów wypowiedzi bohaterów, które wprowadzają czytelnika w niski i wysoki rejestr wypowiedzi; odwołuje się także do polifonicznej struktury powieści i do hybrydowości postaci rozbitej na wiele sfer, tę intymną/wewnętrzną/autentyczną i zewnętrzną/zakamuflowaną/fałszywą. W wersji docelowej tłumacze włoscy dokonują nowego przekładu i interpretacji, kładąc szczególny nacisk na socjologiczną koncepcję „inności”. Włoski odbiorca przygląda się z uwagą zachodzącym przemianom, które dotyczą relacji pomiędzy autorem-narratorem-widzem a bohaterem. Ta nieustanna walka „niespokojnych dusz” w poszukiwaniu własnej tożsamości może być zagrożona utratą własnej osobowości albo inności, tak jak pisał np. P. Ricoeur w O samym sobie; dlatego obserwujemy rodzący się konflikt pomiędzy: być i uchodzić za kogoś, kim się w rzeczywistości nie jest.

Warstwa leksykalna natomiast wskazuje na użycie wyrażeń dialektalnych i idiomatycznych charakterystycznych dla języka hiszpańskiego na Kubie i na Antylach (Haiti); jest nacechowana egzotyką zróżnicowanego i wielopoziomowego świata przyrody (gra kolorów światła - od impresjonizm do ekspresjonizm). Do ciekawych fragmentów opowiadania w języku docelowym należą te, które przedstawiają wypowiedzi w taki sposób, jakby tłumacze chcieli nadać swoim słowom znamiona tajemniczości, niezwykłości, wprowadzając czytelnika w zaczarowany świat folkloru i tradycji kubańskich. Z powodu zastosowania wielu epitetów, zdrobnień, skróconych i urywanych zdań, zmian rejestru językowego, nieprzetłumaczalnych wyrażeń idiomatycznych i szyku traci się często wątek, a samo tłumaczenie dalece odbiega od oryginału. Barokowy styl Carpentiera wraz z leksyką jest nieprzetłumaczalny i stanowi jeden z najważniejszych problemów w tłumaczonych tekstach. Teksty literackie tego pisarza są przepełnione wyszukaną terminologią naukową pochodzącą ze świata przyrody, np.

Marcial [... ] autorizó danzas y tambores de Nación, para distraerse un poco en aquellos dias olientes a perfumes de Colonia, baños de benjuí, y sábanas de armarios que, al abrirse, dejaban caer sobre las losas de mazo de vetiver. El vaho del guarapo 
giraba en el brisa con el toque de oración (1)//Marcial autorizzò balli paesani per distrarsi un poco in quei giorni olezzanti di Colonia, di chiome sciolte e di lenzuola nuove che, nel venir spiegate, lasciavao cader sul pavimento mazzolini di fiore di lavenda. L'afore dei mosti fluttava nella brezza insieme ai rintocchi dell'Avemaria (2).//Marcial autorizzò danze e tamburi di schiavi per distrarsi un poco in quelle giorante odorose di profumi di Colonia, bagni di benzoino, chiome sciolte e lenzuola tolte dagli armandi che aprendosi lasciavano cadere sul pavimento mazzi di vetiveria. I vapori del succo di canna giravano nella brezza col rintocco dell'avemaria (1b), (Carpentier 1962: 227-312).

Jeśli chodzi o zachowanie pewnej egzotyzacji tekstu w języku docelowym, to dostrzegamy wyraźny sygnał obcości i niekonsekwencji, który wynika $z$ wprowadzenia nowych ekwiwalentów leksykalnych, jak m.in. baños de benjuí 'kąpiele drzewicze', a nie „lawendowe” (j. włoski), guarapo 'napój orzeźwiający, słodki', a nie „moszcz” lub „sok z trzciny cukrowej” (j. włoski), vetiver 'eteryczny olejek', a nie „zielona trawa” (j. włoski).

Zastosowane sformułowania lub określenia z języka wyjściowego są niezręczną imitacją wyrażeń dialektalnych i leksykalnych. Tłumacze nie projektują „transferu kulturowego" i nie dekodyfikują elementów związanych z egzotyką i panującymi zwyczajami na wyspie. Dokonują jedynie przeróbki, nie osiągając zamierzonego celu w warstwie leksykalnej; nawet nie używają fenomenu „importu” wyrażeń dialektalnych i leksykalnych, który stanowi o integralności i w części neutralizuje test oryginalny. Dlatego adaptacja oryginału nie jest przekazem transparentnym. Obserwujemy więc, ślady obcości językowej w języku docelowym, a nieprzetłumaczalność niektórych fragmentów tekstu podkreśla różnice pomiędzy kulturami. Sytuacja staje się na tyle trudna, że wynika z niej użycie wyrażeń obcojęzycznych, które nie nadają i nie podkreślają charakteru egzotycznego o wymiarze regionalnym. Tłumacze rezygnują z pozostawienia wyrażeń w wersji oryginalnej, zastępując je ze świadomością konsekwencji i obcości w języku docelowym; czynią to, aby przekład stał się zrozumiały i jasny dla włoskiego czytelnika, nadając stylizacji pewną patynę kolorytu antylskiego krajobrazu i zwyczajów panujących w tym regionie. Carpentier uważany jest za jedynego, unikalnego w swoim rodzaju hiszpańskojęzycznego pisarza, który dzięki inwencji twórczej, niepowtarzalnemu językowi literackiemu, użyciu wielu technik gry słów, zaangażowaniu w tematy społeczne i polityczne Kuby i Europy XX stulecia wskrzesił ludową tradycję rdzennych mieszkańców Kuby sprzed epoki konkwisty.

Podsumowując, należy dojść do kilku interesujących wniosków: tłumaczenie nie może być spłycone, zniekształcone, dowolne i dosłowne, gdyż 
w ten sposób można zbagatelizować tekst, nie przekazując istoty oryginału; tłumaczenia dosłowne i dowolne prowadzą do błędów syntagmatycznych, leksykalnych i kulturowych. Tłumacząc teksty literackie na kilka języków, warto zauważyć, że posługujemy się językami „rodzimymi” - tzw. własnymi i językami „drugimi”, a więc tłumaczonymi, z wyboru; znany hiszpański XX-wieczny literaturoznawca i filozof Miguel de Unamuno podkreślał wielokrotnie, że dzięki poliwalentnej znajomości rodzimego języka można dotrzeć do prawdy o człowieku, odsłaniając o nim nagą prawdę, natomiast w obcych językach można tylko ubrać w odpowiednią szatę to, co pragnie się wyrazić. Dlatego Franca Cavaglioni (Cavaglioni 2012: 24-34), teoretyk przekładoznawstwa, przypomina tłumaczowi z jednej strony o eksperymentowaniu $\mathrm{z}$ formami rodzimego języka i kultury $\mathrm{w}$ ciągłym procesie tłumaczenia, $\mathrm{z}$ drugiej zaś uczula tłumacza na zgłębienie wiedzy na temat autora, kręgu kulturowego, cech stylistycznych tłumaczonych utworów, po to, aby stał się pośrednikiem-mediatorem (między)kulturowym. Koniecznym i niezbędnym kluczem do aplikacji nowego bagażu lingwistycznego i antropologicznego w tłumaczonym tekście jest szeroka znajomość realiów językowych i kulturowych tłumaczonego autora, o czym tłumacz często zapomina. Popada więc w pułapki, m.in. dosłownego lub dowolnego - autorskiego tłumaczenia, które staje się niekiedy alter ego autora, czyli rodzajem nowego plagiatu, (auto)tłumaczenia, w którym przedstawiamy nasze historie.

\section{Literatura}

Bontempelli, M., 1974, Avventura novecentista, Firenze.

Brzozowski, J., 2011, Stanać po stronie tłumacza. Zarys poetyki opisowej przekładu, Kraków.

Carpentier, A., 1970, Viaje a la semilla, Barcelona.

Carpentier, A., 1959, Viaggio alle origini, tłum. A. Araneo, Milano.

Carpentier, A., 1962, Ritorno alle origini, tłum. M. Vasta Dazzi, Milano.

Carpentier, A., 1972, Viaggio verso il seme, tłum. M. Ravoni, Milano.

Cavaglioli, F., 2012, La voce del testo. Larte e il mestiere di tradurre, Milano.

Cortázar, J., 1994, Los relatos 1-4, Madrid.

Cortázar, J., 1994, I racconti, tłum. C. Rizzotti, Torino.

Cortázar, J., 1989, Newpory, tłum. Z. Chądzyńska, Kraków.

Deluese, G., 1972, Neutre, Paris.

Eco, U., 2003, Dire quasi la stessa cosa, Milano.

Folgado, V.L., 1998, „La sangre del espiritù: ideas de Unamuno sobre la len- 
gua y la traducción", [w:] La traducción en torno al 98, M.A. Vega (red.), Madrid.

Hejwowski, K., 2007, Kognitywno-komunikacyjna teoria przekładu, Warszawa.

Iwaszkiewicz, J., 1994, Powrót Prozerpiny, [w:] Nowele włoskie, Warszawa 1994.

Iwaszkiewicz, J., 2012, Il ritorno di Proserpina, Hotel Minerva, dalla Novelle italiane, tłum. C. Bronowski, wprowadzenie D. Tomasello, Pesaro.

Konopnicka, M., 1919, Italia, [w:] I Gioielli de l'Eroica, tłum. M. Loret, Milano.

Konopnicka, M., 2012, Italia, Kraków 2012.

Lejeune, Ph., Bogaet C, 2005, Le journal intime: histoire et anthologie, Paris 2005.

Megnone, L., 2011, Maria Konopnicka. Lustra i symptomy, Gdańsk.

Płaszczewska, O., (red.), 2011, Czytanie Konopnickiej, Kraków 2011

Rulfo, J., 1994, Los cuadernos de Juan Rulfo, Y. Jimenéz de Báez (red.), México.

Rulfo, J., 1960, Pedro Páramo, tłum. E. Mancuso, Milano.

Rulfo, J., 2004, Pedro Páramo,tłum. P. Collo, Torino.

Rulfo, J., 2010, Pedro Páramo, tłum. K. Wojciechowska, Warszawa.

Sgroi, A., 2012, „Testi del Polacco Iwaszkiewicz. La Siracusa del’ 900 diventa un romanzo", [w:] Sicilia z 9.05.

Scimeca, D., 2012, „Iwaszkiewicz - Novelle Italiane - con leggerezza e forza di sogno", [w:] Lios Palermo del Vesprino z 13.08.

Tomaszkiewicz, T., 2007, Przekład audiowizualny, Poznań.

Yurkievich, S., 1984, A través da la trama: sobre vanguardias literarias y otras concomitanicas, Barcelona.

\section{Mirror reflection or optical illusion: on strategies in the translation of literary texts from Polish and Spanish into Italian}

\section{Summary}

The article deals with the problems of translation strategies which concern the works of Polish and Spanish authors belonging to two different cultures, that of Central Europe (Maria Konopnicka and Jarosław Iwaszkiewicz) and that of Latin America (Julio Cortázar, Juan Rulfo, and Alejo Carpentier), seen from the angle of Italian language and culture. The selection of these authors and works is not haphazard: on the one hand, for the Polish writers Italy came to signify an intellectual and anthropological adventure, the country oscillating between realism and fantasy; on the other hand, the elements belonging to Spanish-language magic realism are 
reflected in the new literary translations in Italian, uniting and distancing the cultures of the two continents.

The composition of new Italia by Konopnicka in the Italian translation by Mattia Loreto seems well-structured and ordered; however, it does not constitute a coherent whole of the poet's reflections in terms of themes and philosophy. As a result, we can feel a hint of "poetic dissonance." A cohesive form of the song and the manner of noticing the new world view should become instrumental in the translation because inspiring coherence and melodiousness, which give the whole stanza an intriguing sound, are an immanent feature of Konopnicka's poetics.

The entire translation of two Italian novellas by Iwaszkiewicz, Powrót Prozerpiny and Hotel Minewra, corresponds to the natural use of Italian brought to the contemporary times. For this reason, attention is paid to the translation niceties, which do not result in stylistic dissonance, and sometimes lead to comical, farcical-comical, and grotesque effects, which reflect the content of the original novellas. The translator attempted to keep changes on various levels of the text, which would not lead to a total adaptation but, rather, to a correct translation, so as to render the text clear, coherent, and comprehensible to the foreign receiver, and to make it keep the melody and give the atmosphere of Sicilianness in the Italian language.

The new concept behind magic realism, seen as fantastical-psychological realism, is reflected in the output of Argentinian writer Julio Cortázar. The devices employed by the Italian translators in Deshoras - Niewpory familiarise the reader with the linguistic register of phenomenology. It becomes a projection of the characters' inner reality; and the inversion as well as numerous symbolic allusions, metaphors and periphrases endeavor to be true to the Italian translation. The reality of Mexican writer Juan Rulfo is portrayed in his novel Pedro Páramo. The stylisation of the character's estrangement and of the description of his existence anchored between dream and reality, and life and death, is narrowed down to one dimension: the estrangement of the character in oneiric reality. The grammar structures translated into Italian are slightly changed, but it is without serious consequences to the meaning of the whole text, and it only impoverishes, to a lesser extent, the original sound stratum. The untranslatable word game, transposition, ambiguous use of idiomatic expressions, extension of sentences, descriptive words, and inversion result in a distance from the original text in Spanish. That is why we may experience a feeling of incompleteness and ambivalence of statement. The Italian translators contend with cause and effect relationships present on the temporal and spatial planes. These pose a great challenge to the translator. Moreover, the superimposition and merging of spheres of time and space may cause a lack of logic in further narration or even disruption in the overall translation.

In the Italian translation strategies of Cuban author Alejo Carpentier, the linguistic and lexical plane occupies the most significant place. The linguistic plane concerns the levels of the characters' utterances, which acquaint the reader with low and high registers of the statement; it also refers to the polyphonic structure of the novel and the hybridity of the character broken down into many spheres. In the target version, 
a new translation and interpretation emerge. However, as regards maintaining some exoticisation of the text in the target language, we discern a clear indication of estrangement and inconsistency, which results from the introduction of new lexical equivalents. The translators do not propose any "cultural transfer" and they do not decode the elements connected to exoticism and the customs prevailing on the island: they only make an adaptation, and remain unsuccessful in terms of the lexical stratum.

The translation cannot be oversimplified, distorted, free or literal: these would result in the text being underestimated and deprived of its original essence. The devices/ strategies applied exemplify what may constitute a novelty and continuum in presentday Translation Studies.

Keywords: translation strategies, literary translation, Translation Studies 
